\title{
Impact of Fungicides Chlorothalonil and Propiconazole on Microbial Activities in Groundnut (Arachis hypogaea L.) Soils
}

\author{
A. C. Ramudu, ${ }^{1}$ G. Jaffer Mohiddin, ${ }^{1}$ M. Srinivasulu, ${ }^{1}$ M. Madakka, ${ }^{2}$ and V. Rangaswamy ${ }^{1}$ \\ ${ }^{1}$ Department of Microbiology, Sri Krishnadevaraya University, Anantapur 515055, Andhra Pradesh, India \\ ${ }^{2}$ Department of Biotechnology and Bioinformatics, Yogi Vemana University, Kadapa 516 003, Andhra Pradesh, India
}

Correspondence should be addressed to V. Rangaswamy, rangamanjula@yahoo.com

Received 23 August 2011; Accepted 18 September 2011

Academic Editors: S. H. Flint, V. Juillard, and X. Yu

Copyright ( 2011 A. C. Ramudu et al. This is an open access article distributed under the Creative Commons Attribution License, which permits unrestricted use, distribution, and reproduction in any medium, provided the original work is properly cited.

\begin{abstract}
Introduction of agrochemicals (fungicides) into soil may have lasting effects on soil microbial activities and thus affect soil health. In order to determine the changes in microbial activity in a black clay and red sandy loam soils of groundnut (Arachis hypogaea L.) cultivated fields, a case study was conducted with propiconazole and chlorothalonil to evaluate its effects on soil enzymes (cellulase and invertase) throughout 40 days of incubation under laboratory conditions with different concentrations (1.0, 2.5, 5.0, 7.5, and $10.0 \mathrm{~kg} \mathrm{ha}^{-1}$ ). Individual application of the two fungicides at $1.0,2.5$, and $5.0 \mathrm{~kg} \mathrm{ha}^{-1}$ to the soil distinctly enhanced the activities of cellulase and invertase but at higher concentrations of 7.5 and $10 \mathrm{~kg} \mathrm{ha}^{-1}$ was toxic or innocuous to both cellulase and invertase activities. In soil samples receiving $2.5-5.0 \mathrm{~kg} \mathrm{ha}^{-1}$ of the fungicides, the accumulation of reducing sugar was pronounced more at 20 days, and the activity of the cellulase and invertase was drastically decreased with increasing period of incubation up to 30 and 40 days.
\end{abstract}

\section{Introduction}

The economy of India is largely dependent on the quality and quantity of agricultural produce. Better harvest requires intensive cultivation, irrigation, fertilizers, and more importantly pesticides to protect plants from pests and plant diseases. Pesticides are one of the widely used products developed by man in the last century. They have a beneficial impact not only on agricultural productivity along with the reduction of costs but also on the quality of life and improvement of longevity. It has been reported globally that about $3 \times 10^{9} \mathrm{~kg}$ of pesticides are applied annually [1]. In India, $15-20 \%$ of agricultural production is negatively influenced by pests [2]. Currently, different fungicides are used to protect crops against fungal plant pathogens in agricultural practices and maintain high crop production in modern agriculture. Groundnut (Arachis hypogaea L.) is one of the important major, profitable oil seed crop grown throughout the year in India [3]. Groundnut ranks seventh among crops in terms of insecticide consumption in India. It contributes to $41.3 \%$ of countries oil seed production [4]. When a pesticide is released deliberately or accidentally into the environment, about $0.1 \%$ is reaching the target organism, while the remaining $0.99 \%$ not only troubles local metabolism or enzymatic activities [5-9], but also disturbs soil ecosystem, and thus may affect human health by entering in the food chain, which has raised considerable public concern. So, from past 10 decades, more specific prominence has been given to soil enzymes because these are indicators of biological equilibrium, fertility, quality [10-12] and changes in the biological status of soil due to pollution $[13,14]$. When compared with enzymes from different sources, soil enzymes commonly show particular and peculiar feature. Soil enzymes are involved in energy transfer, nutrient cycling, environmental quality, and crop productivity. Negative impact of pesticides on soil enzymes like hydrolases, oxidoreductases, and dehydrogenase activities has been widely reported in the literature $[15,16]$. But on cellulase and invertase, too little literature is available on chlorothalonil and propiconazole (fungicides). Cellulase and invertase enzymes are also very important enzymes involved in the transformation/decomposition of organic matter in soil. Cellulase catalyzes hydrolysis of cellulose to D-glucose. Invertase is a ubiquitous enzyme that occurs in plant tissues and soil 
organisms $[17,18]$. Invertase hydrolyze sucrose to fructose and glucose. As previously reviewed by so many researchers, several studies $[15,19-22]$ have been performed on the impact of pesticides on soil microbial activity, and application of pesticides increased, decreased, or did not affect the activities of these enzymes in soils, depending upon the nature and concentrations of pesticides used, incubation period, status of enzymes in soil, and soil condition. Chlorothalonil (2, 4, 5, 6-tetrachloroisopthalonitrile), a nonsystemic widely used foliar fungicide for the control of plant pathogens causing broad spectrum of plant diseases in agricultural systems. Propiconazole is a systemic foliar fungicide with a broad range of activity. It is used on grasses grown for seed, mushrooms, corn, wild rice, peanuts, almonds, sorghum, oats, pecans, apricots, peaches, nectarines, plums, and prunes. Therefore, investigating effects of contaminants on enzymatic activity may evaluate the soil microbial properties and further prove extremely useful in risk assessment.

\section{Materials and Methods}

2.1. Soils Used in the Present Study. Two soils, a black clay soil and red sandy loam soil, were collected randomly from different sites of groundnut cultivated fields of Anantapur district of Andhra Pradesh, India, near the rhizosphere zone (a zone of increased microbial and enzyme activity where soil and root make contact) using trowel at a depth of 0-12 centimeters and mixed thoroughly to prepare a homogenate composite sample, air-dried at room temperature samples were cleaned by removing plant material and other debris, passed through 2 millimeter sieve, stored at $4^{\circ} \mathrm{C}$ prior to analysis. Mineral matter of soil samples were done by the following methods. Soil $\mathrm{pH}$ was determined by using $1: 1.25$ soils to water ratio in systronic digital $\mathrm{Ph}$ meter [23]. Organic matter in soil samples was estimated by Walkley-Black method [24], and total nitrogen content in soil samples was determined by Micro-Kjeldhal method [24]. Electrical conductivity was measured by conductivity bridge and contents of nitrite-nitrogen [25] by Brucine method [26]. The important physicochemical properties of the two soils were furnished in Table 1.

2.2. Insecticides Used in the Present Study. To determine the influence of selected insecticides on soil enzyme activities, propiconazole ( $25 \%$ emulsifying concentration*), and chlorothalonil ( $75 \%$ wettable powder*) was obtained from Sergeant India Ltd. 14, Tata Road, Mumbai-20. Obtained commercial insecticides were dissolved in distilled water.

\subsection{Soil Incubation Studies}

2.3.1. Cellulase and Invertase Activities. Five-gram portions of soil samples were weighed and dispersed into sterile test tubes $(25 \times 150 \mathrm{~mm})$. Stock solutions from selected fungicides were added at the rate of $10,25,50,75$, and $100 \mu \mathrm{gg}^{-1}$ soil, which are equivalent to field application rates of 1.0, 2.5, 5.0, 7.5, and $100 \mathrm{~kg} \mathrm{ha}^{-1}$, respectively. Soil samples without fungicides treatment served as controls. Soil samples were mixed thoroughly for uniform distribution
TABLE 1: Physico-characteristic of the soils.

\begin{tabular}{lcc}
\hline Properties & $\begin{array}{c}\text { Black clay } \\
\text { soil }\end{array}$ & $\begin{array}{c}\text { Red sandy } \\
\text { loam soil }\end{array}$ \\
\hline Sand $(\%)$ & 68.3 & 53.3 \\
Silt $(\%)$ & 22.7 & 27.1 \\
Clay $(\%)$ & 09.0 & 19.6 \\
$\mathrm{pH}^{\mathrm{a}}$ & 7.7 & 6.6 \\
${\text { Water holding capacity }\left(\mathrm{mL} \mathrm{g}^{-1} \text { soil }\right)}^{\text {Electrical conductivity }(\mathrm{m} . \mathrm{mhos})}$ & 0.47 & 0.27 \\
Organic matter ${ }^{\mathrm{b}}(\%)$ & 254 & 238 \\
Total nitrogen $^{\mathrm{c}}(\%)$ & 1.44 & 0.72 \\
$\mathrm{NH}_{4}{ }^{+}-\mathrm{N}\left(\mu \mathrm{g} \mathrm{g}^{-1} \text { soil }\right)^{\mathrm{d}}$ & 0.084 & 0.042 \\
$\mathrm{NO}_{2}{ }^{-}-\mathrm{N}\left(\mu \mathrm{g} \mathrm{g}^{-1} \text { soil }\right)^{\mathrm{e}}$ & 7.96 & 7.01 \\
$\mathrm{NO}_{3}{ }^{-}-\mathrm{N}\left(\mu \mathrm{g} \mathrm{g}^{-1} \text { soil }\right)^{\mathrm{f}}$ & 0.48 & 0.32 \\
\hline
\end{tabular}

where, ${ }^{\mathrm{a}} 1: 1.25=$ soil $:$ water slurry.

${ }^{b}$ Walkley-Black method [24].

${ }^{c}$ Micro-Kjeldahl metod [24].

${ }^{\mathrm{d}}$ Nesslerization method [24].

eDiazotization method [25].

${ }^{\mathrm{f}}$ Brucine method [26].

of fungicides added. Triplicates were maintained for each treatment at room temperature $\left(28 \pm 4^{\circ} \mathrm{C}\right)$ with $60 \%$ water holding capacity throughout the incubation period. After desired intervals of incubation, soil samples were extracted in distilled water for estimation of enzyme activities.

2.4. Assay of Cellulase (EC 3.2.1.4.). In order to determine cellulase enzyme activity in soils, $10 \mathrm{~mL}$ of carboxy methyl cellulose (CMC) 1\% was used as a substrate followed by $10 \mathrm{~mL}$ of acetate buffer ( $\mathrm{pH}$ 5.9) and incubated for 24 hours to determine the reducing sugar content in the filtrate [27]. In another experiment, rate of enzyme activity cellulase were determined at 10,20,30, and 40 days of soil incubation and further with the respective suitable substrate.

2.5. Assay of Invertase (EC 3.2.1.26). The method employed for assay of invertase was developed by [28] and followed by $\mathrm{Tu}[29,30]$. The soil samples were transferred to $100 \mathrm{~mL}$ Erlenmeyer flasks and were treated with $1 \mathrm{~mL}$ of toluene to arrest the enzyme activity. After 15 minutes, $6 \mathrm{~mL}$ of $18 \mathrm{mM}$ sucrose was added to the soil samples and incubated for 24 and 48 hours, the testing samples were passed through Wattman no. 1 filter paper, and the filtrate was assayed for the amount of glucose by Nelson somagi method [31] in a spectronic $20 \mathrm{D}$ spectrophotometer. In another experiment, rate of enzyme activitiy invertase were determined at 10 , 20,30 , and 40 days of soil incubation and further with the respective suitable substrate.

2.6. Statistical Analysis. The concentration of the cellulase and invertase was calculated on the basis of soil weight (oven dried). Data were analyzed using one-way ANOVA and the differences contrasted using Duncan's multiple range test (DMRT) $[19,32]$. All statistical analysis was performed at $P \leq 0.05$ using SPSS statistical software package. 
TABLE 2: Activity of cellulase* under the impact of different concentrations of selected fungicides propiconazole and chlorothalonil in soils incubated for 24 hours after 10 days.

\begin{tabular}{lcccc}
\hline $\begin{array}{l}\text { Concentration of } \\
\begin{array}{l}\text { fungicides } \\
\left(\mathrm{Kg} \mathrm{ha}^{-1}\right)\end{array}\end{array}$ & $\begin{array}{c}\text { Propiconazole } \\
(\text { Tilt })\end{array}$ & $\begin{array}{c}\text { Black clay soil } \\
\text { Chlorothalonil } \\
\text { Kavach) }\end{array}$ & $\begin{array}{c}\text { Propiconazole } \\
\text { (Tilt) }\end{array}$ & $\begin{array}{c}\text { Red sandy loam soil } \\
\text { Chlorothalonil } \\
(\text { Kavach })\end{array}$ \\
\hline 0.0 & $455 \pm 2.886^{\mathrm{a}}$ & $455 \pm 2.886^{\mathrm{a}}$ & $375 \pm 5.773^{\mathrm{a}}$ & $375 \pm 5.773^{\mathrm{a}}$ \\
1.0 & $496 \pm 5.773^{\mathrm{a}}$ & $471 \pm 11.547^{\mathrm{a}}$ & $431 \pm 17.320^{\mathrm{b}}$ & $415 \pm 8.660^{\mathrm{b}}$ \\
2.5 & $616 \pm 3.464^{\mathrm{b}}$ & $575 \pm 5.774^{\mathrm{b}}$ & $525 \pm 2.886^{\mathrm{c}}$ & $505 \pm 1.732^{\mathrm{b}}$ \\
5.0 & $750 \pm 11.547^{\mathrm{c}}$ & $726 \pm 1.154^{\mathrm{c}}$ & $695 \pm 2.886^{\mathrm{d}}$ & $688 \pm 1.732^{\mathrm{c}}$ \\
7.5 & $619 \pm 1.154^{\mathrm{d}}$ & $554 \pm 2.309^{\mathrm{d}}$ & $505 \pm 2.886^{\mathrm{c}}$ & $496 \pm 1.154^{\mathrm{b}}$ \\
10.0 & $449 \pm 0.577^{\mathrm{a}}$ & $436 \pm 4.618^{\mathrm{a}}$ & $345 \pm 2.886^{\mathrm{e}}$ & $324 \pm 1.154^{\mathrm{d}}$ \\
\hline
\end{tabular}

Each column is mean \pm S.E. for six concentrations in each group; columns not sharing a common letter (a, b, $c, d$ and e) differ significantly with each other $(P \leq 0.05$; DMRT $)$.

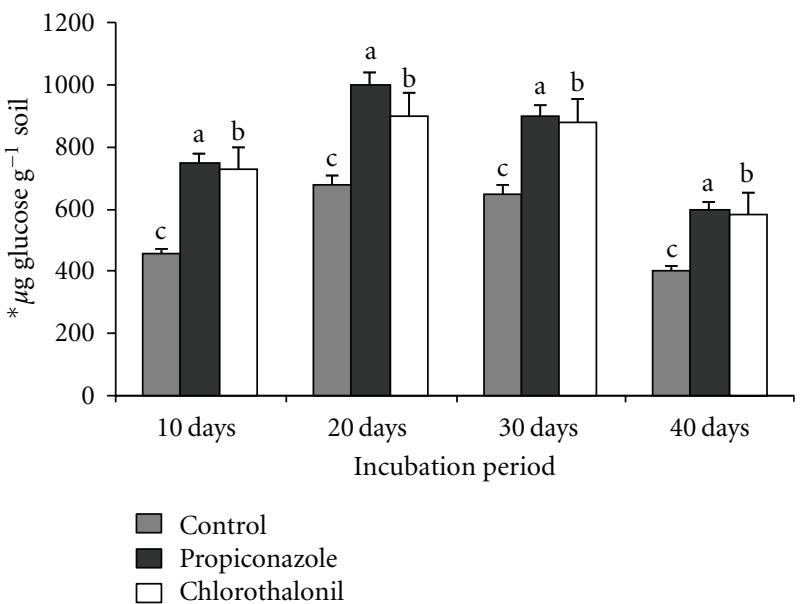

(a)

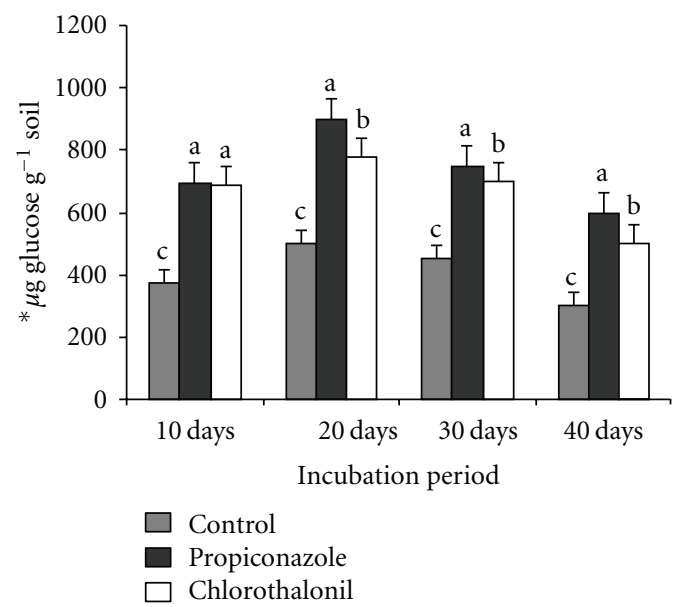

(b)

Figure 1: Influence of fungicides at $5.0 \mathrm{~kg} \mathrm{ha}^{-1}$ on cellulase* activity in black clay soil (a) and red sandy loam soil (b) * $\mu$ g of glucose per gram soil formed after 24 hours with $1 \%$ carboxy methyl cellulose (CMC) after 10, 20, 30, and 40 days. The values are the means \pm S.E. for each incubation period, followed by the different letter are significantly different $(P \leq 0.05)$ from each other according to Duncan's multiple range (DMR) test.

\section{Results}

3.1. Cellulase (EC 3.2.1.4.). The effect of different application rates of chlorothalonil and propiconazole on cellulase activity is presented in Table 2. After 10 days of incubation enzyme activity increased in all the treatments $(1.0,2.5,5.0$, and $7.5 \mathrm{~kg} \mathrm{ha}^{-1}$ ) except at $10.0 \mathrm{~kg} \mathrm{ha}^{-1}$ level. The maximum cellulase activity was observed at $5.0 \mathrm{~kg} \mathrm{ha}^{-1}$ (stimulatory) and lowest activity at $10.0 \mathrm{~kg} \mathrm{ha}^{-1}$ level. The cellulase activity was significantly enhanced at $5.0 \mathrm{~kg} \mathrm{ha}^{-1}$ level in both soils for chlorothalonil and propiconazole showed individual increments of cellulase activity ranged from a low increase $3-59 \%, 10-83 \%, 9-65 \%$, and $15-85 \%$ in comparison to control (Table 2). The stimulatory concentration $\left(5.0 \mathrm{~kg} \mathrm{ha}^{-1}\right)$ induces the highest enzymatic activity after 20, 30, and 40 days of incubation in both soils (Figures 1(a) and 1(b)) when compared to control. A further increase in the incubation period of stimulatory concentration of fungicides decreased the rate of cellulase activity after 20 days and then decline phase was started from 20 to 40 days of incubation (Figures $1(\mathrm{a})$ and $1(\mathrm{~b}))$.
3.2. Invertase (EC 3.2.1.26). Invertase activity (Tables 3(a) and $3(\mathrm{~b})$ ) showed a variable pattern in response to different fungicide concentration after 10 days of incubation. Enzyme activity increased under all the treatments (1.0, 2.5, 5.0, and $7.5 \mathrm{~kg} \mathrm{ha}^{-1}$ ) except $10 \mathrm{~kg} \mathrm{ha}^{-1}$ level compared to the controls in both soils. The maximum activity was observed at $5.0 \mathrm{~kg} \mathrm{ha}^{-1}$ (stimulatory) for chlorothalonil and $2.5 \mathrm{~kg} \mathrm{ha}^{-1}$ (stimulatory) for propiconazole, lowest activity at $10.0 \mathrm{~kg} \mathrm{ha}^{-1}$ level for both fungicides in both soils (Tables $3(\mathrm{a})$ and $3(\mathrm{~b})$ ). chlorothalonil and propiconazole showed individual increments of invertase activity ranged from a low increase $8-43 \%, 21-63 \%$ and $10-39 \%, 7-49 \%$ in comparison to control at $24 \mathrm{hrs}$ and for $48 \mathrm{hrs} 2-33 \%, 12-48 \%$ and 9-130\%, 9-40\% received 5.0 and $2.5 \mathrm{~kg} \mathrm{ha}^{-1}$, respectively (Table 3 ). The stimulatory concentration induces the highest enzymatic activity after 20,30, and 40 days of incubation in comparison with control in both soils (Figures 2(a) and 2(b)). With further increase in the incubation periods for a prolonged period (up to 40 days), the stimulatory concentration of fungicides decreased the rate of invertase 
TABle 3: Activity of invertase* under the impact of different concentrations of selected fungicides in Black clay soil (a) and Red sandy loam soil (b) for 24 hours and 48 hours after 10 days.

(a)

\begin{tabular}{lccrr}
\hline $\begin{array}{l}\text { Concentration of } \\
\text { fungicides }\left(\mathrm{Kg} \mathrm{ha}^{-1}\right)\end{array}$ & \multicolumn{2}{c}{ Propiconazole (Tilt) } & \multicolumn{2}{c}{ Chlorothalonil (Kavach) } \\
& $24 \mathrm{hrs}$ & $48 \mathrm{hrs}$ & $24 \mathrm{hrs}$ & $48 \mathrm{hrs}$ \\
\hline 0.0 & $827 \pm 1.154^{\mathrm{a}}$ & $915 \pm 8.660^{\mathrm{a}}$ & $827 \pm 1.154^{\mathrm{a}}$ & $915 \pm 1.154^{\mathrm{a}}$ \\
1.0 & $911 \pm 5.773^{\mathrm{b}}$ & $1002 \pm 1.154^{\mathrm{b}}$ & $896 \pm 2.309^{\mathrm{b}}$ & $931 \pm 17.320^{\mathrm{b}}$ \\
2.5 & $1152 \pm 1.154^{\mathrm{c}}$ & $1190 \pm 1.154^{\mathrm{c}}$ & $976 \pm 1.732^{\mathrm{c}}$ & $1062 \pm 1.154^{\mathrm{b}}$ \\
5.0 & $963 \pm 1.732^{\mathrm{d}}$ & $1064 \pm 1.154^{\mathrm{d}}$ & $1183 \pm 1.732^{\mathrm{d}}$ & $1220 \pm 2.309^{\mathrm{d}}$ \\
7.5 & $904 \pm 2.309^{\mathrm{b}}$ & $984 \pm 0.577^{\mathrm{e}}$ & $963 \pm 1.732^{\mathrm{e}}$ & $1002 \pm 1.154^{\mathrm{d}}$ \\
10.0 & $751 \pm 0.577^{\mathrm{e}}$ & $821 \pm 0.577^{\mathrm{f}}$ & $726 \pm 1.732^{\mathrm{f}}$ & $848 \pm 1.154^{\mathrm{e}}$ \\
\hline
\end{tabular}

(b)

\begin{tabular}{lcccc}
\hline $\begin{array}{l}\text { Concentration of } \\
\text { fungicides }\left(\mathrm{Kg} \mathrm{ha}^{-1}\right)\end{array}$ & \multicolumn{2}{c}{ Propiconazole (Tilt) } & \multicolumn{2}{c}{ Chlorothalonil (Kavach) } \\
& $24 \mathrm{hrs}$ & $48 \mathrm{hrs}$ & $24 \mathrm{hrs}^{2}$ & $48 \mathrm{hrs}$ \\
\hline 0.0 & $827 \pm 1.154^{\mathrm{a}}$ & $915 \pm 8.660^{\mathrm{a}}$ & $827 \pm 1.154^{\mathrm{a}}$ & $915 \pm 1.154^{\mathrm{a}}$ \\
1.0 & $911 \pm 5.773^{\mathrm{b}}$ & $1002 \pm 1.154^{\mathrm{b}}$ & $896 \pm 2.309^{\mathrm{b}}$ & $931 \pm 17.320^{\mathrm{b}}$ \\
2.5 & $1152 \pm 1.154^{\mathrm{c}}$ & $1190 \pm 1.154^{\mathrm{c}}$ & $976 \pm 1.732^{\mathrm{c}}$ & $1062 \pm 1.154^{\mathrm{b}}$ \\
5.0 & $963 \pm 1.732^{\mathrm{d}}$ & $1064 \pm 1.154^{\mathrm{d}}$ & $1183 \pm 1.732^{\mathrm{d}}$ & $1220 \pm 2.309^{\mathrm{d}}$ \\
7.5 & $904 \pm 2.309^{\mathrm{b}}$ & $984 \pm 0.577^{\mathrm{e}}$ & $963 \pm 1.732^{\mathrm{e}}$ & $1002 \pm 1.154^{\mathrm{d}}$ \\
10.0 & $751 \pm 0.577^{\mathrm{e}}$ & $821 \pm 0.577^{\mathrm{f}}$ & $726 \pm 1.732^{\mathrm{f}}$ & $848 \pm 1.154^{\mathrm{e}}$ \\
\hline
\end{tabular}

Each column is mean \pm S.E. for six concentrations in each group; columns not sharing a common letter (a, b, $c$, d, e, and f) differ significantly with each other $(P \leq 0.05$; DMRT).

activity after 30 days, and then, decline phase was started from 30 to 40 days of incubation (Figures 2(a) and 2(b)).

\section{Discussion}

The activity of invertase, as evidenced by the accumulation of glucose formed from sucrose was consistently more than that of cellulase activity in soil samples. In both red sandy loam soil and black clay soil samples, the concentrations ranging from $1.0-5.0 \mathrm{~kg} \mathrm{ha}^{-1}$ were either stimulatory or innocuous to the enzyme activity. However, treated with $2.5 \mathrm{~kg} \mathrm{ha}^{-1}$ of tilt and $5.0 \mathrm{~kg} \mathrm{ha}^{-1}$ of kavach in both soils showed maximum enzyme activity at the end of 24 and 48 hrs of incubation with substrate (i.e., sucrose). Application of these fungicides at $7.5 \mathrm{~kg} \mathrm{ha}^{-1}$ and $10.0 \mathrm{~kg} \mathrm{ha}^{-1}$ significantly inhibited the formation of glucose from sucrose. The data presented in Tables 3(a) and 3(b) showed the activity of invertase under the influence of different concentrations (1.0, $2.5,5.0,7.5$, and $10.0 \mathrm{~kg} \mathrm{ha}^{-1}$ ) of fungicides after 10 days of incubation. In all untreated red and black soil samples, invertase activity was significantly more at 20-day incubation when compared with 10-day, 30-day, and 40-day incubated soil samples (Figures 2(a) and 2(b)). All the treated soil samples showed their assayed enzyme activity more in the soil samples of 20-day incubation when compared with 10days, 30-days, and 40-day incubation (Figures 2(a) and 2(b)). The soil samples (black and red) treated with $2.5 \mathrm{~kg} \mathrm{ha}^{-1}$ of tilt and $5.0 \mathrm{~kg} \mathrm{ha}^{-1}$ of kavach, the enzyme activity was more (Figures 2(a) and 2(b)). Further more this increase in glucose concentration was striking when the substrate was exposed to the soil samples for $48 \mathrm{hrs}$. For minor variations in enzyme activity, both (tilt and kavach) fungicides exhibited stimulatory effect significantly until 20 days. Prolonged incubation (up to 40 days) of fungicide-treated soil samples showed either stimulation or no measurable effect on the enzyme activity. When compared the results with others on the invertase activity [20,33-36], the results obtained were similar. Comparatively, in the present study, the black soil showed higher enzyme activity than the red soil throughout the experiment. It is usually concluded that high enzymatic activities are associated with higher organic matter content, $\mathrm{Tu}$ [33] reported two fungicides, triazophos a phosphorothioate triazole and the invertase activity was increased to 10-fold. A similar effect was observed with respect to thiram [34]. On the contrary, captan and maneb, at the same concentrations and incubation period, had no effect on invertase activity [29, 30, 33]. The authors in [37] demonstrated that captafol and chlorothalonil suppressed invertase activity for one day temporarily in a sandy loam soil, and later on, after 2 days, the inhibitory effect diminished. Similarly, Srinivasulu and Rangaswamy [20] reported decrease in the invertase activity at higher concentrations $\left(7.0\right.$ and $\left.10.0 \mathrm{~kg}^{-1} \mathrm{ha}\right)$ by the application of tridemorph and captan. The activity of invertase was significantly inhibited by chlorothalonil up to $37.7 \%, 13.9$, and 34.2\%, respectively [21]. Yan et al., [38] noticed that, the carbendazim $\left(8.0 \mathrm{mg} \mathrm{kg}^{-1}\right)$ and chloramphenicol showed inhibitory effect on invertase activity. 


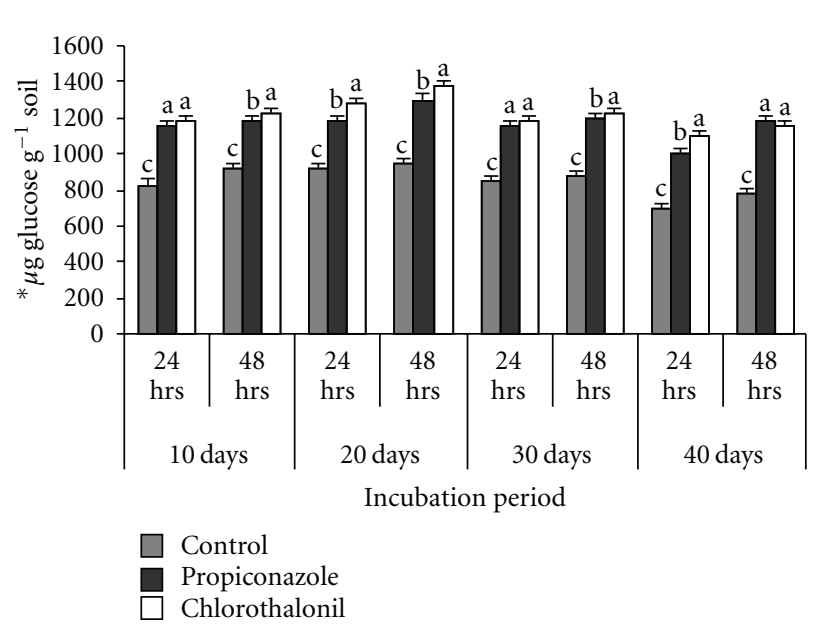

(a)

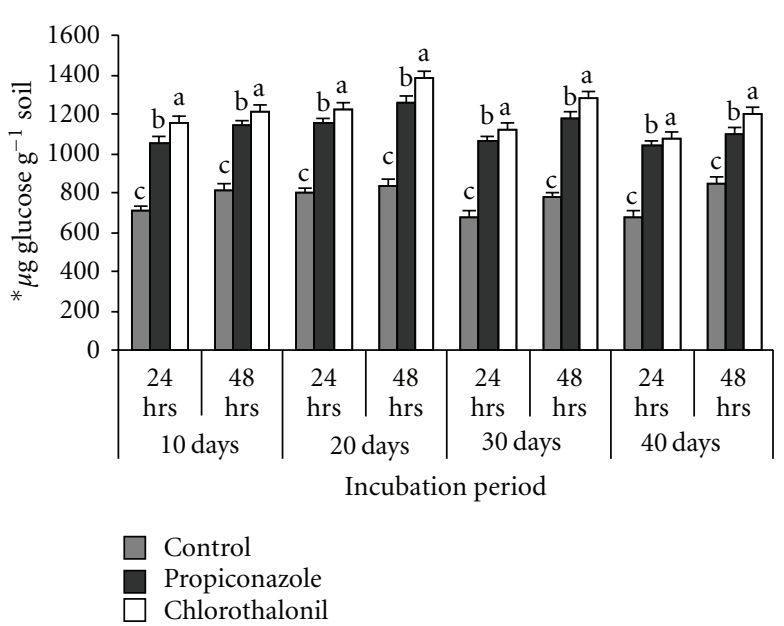

(b)

FIGURE 2: Influence of fungicides at $2.5 \mathrm{~kg} \mathrm{ha}^{-1}$ on invertase* activity in black clay soil (a) and red sandy loam soil (b) after 24 and 48 hours. ${ }^{*} \mu$ g glucose per gram soil formed after 24 and $48 \mathrm{hrs}$ incubation with $18 \mathrm{mM}$ sucrose. After 10, 20, 30, and 40 days. The values are the means \pm S.E. for each incubation period, followed by the different letter which are significantly different $(P \leq 0.05)$ from each other according to Duncan's multiple range (DMR) test.

A negative correlation was observed between the napropamide and invertase activity by Guo et al., [39]. The outcome of this investigation fairly indicates that the fungicides used in agriculture at levels nearer to field doses significantly enhanced the invertase activity in soil environment.

The method developed and used for the assay of cellulase activity in soils is based on colorimetric determination of reducing sugars in soil extracts formed from the carboxy methylcellulose in the presence of soil cellulase. Glucose formed from carboxy methylcellulose (CMC) was significantly more in both red sandy loam and black clay soil samples treated with $5.0 \mathrm{~kg} \mathrm{ha}^{-1}$ (Table 2) of propiconazole and chlorothalonil which showed more cellulose activity. Application of fungicides at $7.5 \mathrm{~kg} \mathrm{ha}^{-1}$ and $10.0 \mathrm{~kg} \mathrm{ha}^{-1}$ significantly inhibited the formation of glucose from CMC. The data presented in the Table 2 showed the activity of cellulase under influence of different concentrations (1.0, 2.5, 5.0, 7.5, and $10.0 \mathrm{~kg} \mathrm{ha}^{-1}$ ) of fungicides after 10 days. Rangaswamy and Venkateswarlu in [22] noticed that the insecticides at higher concentrations of 7.5 and $10.0 \mathrm{~kg} \mathrm{ha}^{-1}$ were toxic to cellulase activity. Jayamadhuri [35] and Jayamadhuri and Rangaswamy [36] reported that higher concentrations (7.5 and $10 \mathrm{~kg} \mathrm{ha}^{-1}$ ) of fungicides reduce the enzyme activity. In all the untreated red sandy loam soil and black clay soil samples, The amount of glucose formed from cellulose was significantly more at 20 day incubation, when compared with 10-days, 30-days, and 40-days incubated samples (Figures 1 (a) and 1(b)). Similarly, all the treated soil samples showed their assayed enzyme activity more in the soil samples of 20 days incubation when compared with 10-days, 30-days, and 40-days incubation. As for the soil samples treated with propiconazole and chlorothalonil, enzyme activity was more at concentrations of $5.0 \mathrm{~kg} \mathrm{ha}^{-1}$. Expect for minor variations in enzyme activity, all the fungicides exhibited stimulatory effect significantly until 20 days after their application. Prolonged incubation (up to 40 days) of fungicides-treated soil samples showed either stimulation or no measurable effect on the enzyme activity. Tu [33, 34], Jayamadhuri [35], and Jayamadhuri and Rangaswamy [36] observed similar trend of cellulase activity. However, high concentrations of 7.5 and $10.0 \mathrm{~kg} \mathrm{ha}^{-1}$ levels of two fungicidal treatments had innocuous effect on cellulase activity in both soil samples (Table 2). Similarly, an anthraquic fluvisol soil incubated with the formulated fungicide, hymexazol for 4 weeks remained unchanged in cellulolytic activity [40]. From the experimental data, it is clear that stimulatory effect was comparatively more in black clay soil than red sandy loam soil (Table 2). The stimulatory effect on cellulase activity was maximum at $5.0 \mathrm{~kg} \mathrm{ha}^{-1}$ in both soils, exerted by two fungicidal treatments (Table 2). Similarly, the cellulase activity was promoted at $50 \mathrm{ppm}$ by pyrazofos (as afugan) and propiconazole (as tilt) in soils inoculated with root fungi faba bean pots [41]. Captafol, at 10 parts $/ 10^{6}$, was significantly inhibited mineralization of cellulose in a sandy loam soil [42]. A distinct depression was observed with chlorothalonil, under all conditions tested, that is, at the usual dose, in both flooded and nonflooded soil [43]. Similarly, trichlamide at 10 times recommended field rate (i.e., $400 \mathrm{mg} / \mathrm{kg}$ ) incubated for 4 weeks under flooded soil conditions, inhibited the cellulolytic activity completely. Whereas the usual field rate the activity was about 50\% that in the control soil [40]. Further Petker and Rai [44] demonstrated that five fungicides, captan, cosan, thiram, zineb, and sandolex, inhibited the cellulase activity, with greater inhibition with increasing fungicidal concentrations. According to Arinze and Yubedee [45], benlate, calixin, and captan inhibited the activity of cellulase in Fusarium monoliforme isolates.

\section{Conclusion}

The results obtained in the present study clearly indicate that the fungicides chlorothalonil and propiconazole profoundly 
enhanced the activities of both cellulase and invertase at field application rates. On the basis of these results, it is concluded that the microbial activities (i.e., enzyme activities) were increased by the fungicides applied at recommended levels in agricultural system to control insect pests.

\section{Acknowledgment}

The authors are thankful to the Sri Krishnadevaraya University authorities for providing necessary facilities throughout research work.

\section{References}

[1] Pan-UK, "Current pesticide spectrum, global use and major concerns," 2003, http://www.pan-uk.org/.

[2] T. S. Bhalerao and P. R. Puranik, "Biodegradation of organochlorine pesticide, endosulfan, by a fungal soil isolate, Aspergillus niger," International Biodeterioration and Biodegradation, vol. 59, no. 4, pp. 315-321, 2007.

[3] P. Guha and S. C. Chandra sekhar, "Efficacy \& residues of propiconazole 25\% EC in groundnut," Pestalogy, vol. 23, no. 7, pp. 57-59, 2001.

[4] R. S. Giraddi, S. Lingappa, and R. Hegde, "Bioefficacy of new wettable powders on leaf eating caterpillars of groundnut," Pestology, vol. 23, no. 7, pp. 57-59, 1999.

[5] J. F. Carriger, G. M. Rand, P. R. Gardinali, W. B. Perry, M. S. Tompkins, and A. M. Fernandez, "Pesticides of potential ecological concern in sediment from south Florida canals: an ecological risk prioritization for aquatic arthropods," Soil and Sediment Contamination, vol. 15, no. 1, pp. 21-45, 2006.

[6] D. Pimentel, "Amounts of pesticides reaching target pests: environmental impacts and ethics," Journal of Agricultural and Environmental Ethics, vol. 8, no. 1, pp. 17-29, 1995.

[7] B. Engelen, K. Meinken, F. Von Wintzingerode, H. Heuer, H.P. Malkomes, and H. Backhaus, "Monitoring impact of a pesticide treatment on bacterial soil communities by metabolic and genetic fingerprinting in addition to conventional testing procedures," Applied and Environmental Microbiology, vol. 64, no. 8, pp. 2814-2821, 1998.

[8] J. Liu, J. Xie, Y. Chu, C. Sun, C. Chen, and Q. Wang, "Combined effect of cypermethrin and copper on catalase activity in soil," Journal of Soils and Sediments, vol. 8, no. 5, pp. 327-332, 2008.

[9] E. Topp, T. Vallaeys, and G Soulas, "Pesticides: microbial degradation and effects on microorganisms," in Modern Soil Microbiology, J. D. van Elsas, J. T. Trevors, and E. M. H. Wellington, Eds., pp. 547-575, Marcel Dekker, New York, NY, USA, 1997.

[10] W. T. Frankenberger Jr. and M. A. Tabatabai, "l-glutaminase activity of soils," Soil Biology and Biochemistry, vol. 23, no. 9, pp. 869-874, 1991.

[11] G. F. Antonious, "Impact of soil management and two botanical insecticides on urease and invertase activity," Journal of Environmental Science and Health - Part B, vol. 38, no. 4, pp. 479-488, 2003.

[12] J. Z. Burket and R. P. Dick, "Microbial and soil parameters in relation to $\mathrm{N}$ mineralization in soils of diverse genesis under differing management systems," Biology and Fertility of Soils, vol. 27, no. 4, pp. 430-438, 1998.

[13] P. Nannipieri, S. Grego, and B. Ceccanti, "Ecological significance of the biological activity in soil," in Soil Biochemistry,
J.-M. Bollag and G. Stozky, Eds., vol. 6, pp. 293-355, Marcel Dekker, New York, NY, USA, 1990.

[14] C. Trasar-Cepeda, M. C. Leirós, S. Seoane, and F. Gil-Sotres, "Limitations of soil enzymes as indicators of soil pollution," Soil Biology and Biochemistry, vol. 32, no. 13, pp. 1867-1875, 2000.

[15] B. S. Ismail, K. F. Yapp, and O. Omar, "Effects of metsulfuronmethyl on amylase, urease, and protease activities in two soils," Australian Journal of Soil Research, vol. 36, no. 3, pp. 449-456, 1998.

[16] P. Menon, M. Gopal, and R. Parsad, "Effects of chlorpyrifos and quinalphos on mineralization in soils of diverse genesis under differing management systems," Biology and Fertility of Soils, vol. 27, pp. 430-438, 2005.

[17] J. Skujinss, "Extracellular enzymes in soil," CRC critical reviews in microbiology, vol. 4, no. 4, pp. 383-421, 1976.

[18] W. T. Frankenberger Jr. and M. A. Tabatabai, "2-glutaminase activity of soils," Soil Biology \& Biochemistry, vol. 23, pp. 869874, 1991.

[19] G. Jaffer Mohiddin, M. Srinivasulu, M. Madakka, and V. Rangaswamy, "Influence of insecticides on the activity of amylase and cellulase in groundnut soils," Ecology, Environment and Conservation, vol. 16, no. 3, pp. 383-388, 2010.

[20] M. Srinivasulu and V. Rangaswamy, "Activities of invertase and cellulase as influenced by the application of tridemorph and captan to groundnut (Arachis hypogaea) soil," African Journal of Biotechnology, vol. 5, no. 2, pp. 175-180, 2006.

[21] L. Y. Yun, M. Shan, H. Fang, X. Wang, and Q. C. Xiao, "Responses of soil microorganisms and enzymes to repeated applications of chlorothalonil," Journal of Agricultural and Food Chemistry, vol. 54, no. 26, pp. 10070-10075, 2006.

[22] V. Rangaswamy and K. Venkateswarlu, "Activities of amylase and invertase as influenced by the application of monocrotophos, quinalphos, cypermethrin and fenvalerate to groundnut soil," Chemosphere, vol. 25, no. 4, pp. 525-530, 1992.

[23] C. M. Johnson and A. Ulrich, "Determination of moisture in plant tissues," California Agriculture Bulletin, vol. 766, pp. 112-115, 1960.

[24] M. L. Jackson, Soil Chemical Analysis, Prentice Hall, New Delhi, India, 1971.

[25] T. A. Ranney and R. J. Bartlett, "Rapid field determination of nitrate in natural waters," Communications in Soil Science and Plant Analysis, vol. 3, pp. 183-186, 1972.

[26] H. Barnes and A. R. Folkard, "The determination of nitrites," The Analyst, vol. 76, no. 907, pp. 599-603, 1951.

[27] S. P. Deng and M. A. Tabatabai, "Cellulase activity of soils," Soil Biology and Biochemistry, vol. 26, no. 10, pp. 1347-1354, 1994.

[28] M. A. Cole, "Lead inhibition of enzyme synthesis in soil," Applied and Environmental Microbiology, vol. 33, no. 2, pp. 262-268, 1977.

[29] C. M. Tu, "Effects of pesticides on activities of enzymes and microorganisms in a clay soil," Journal of Environmental Science and Health - Part B, vol. 16, no. 2, pp. 179-191, 1981.

[30] C. M. Tu, "Effects of some pesticides on enzyme activities in an organic soil," Bulletin of Environmental Contamination and Toxicology, vol. 27, no. 1, pp. 109-114, 1981.

[31] N. Nelson, "A photometric adapatation of Somogyi method for determination of glucose," Journal of Biological Chemistry, vol. 153, pp. 375-380, 1944.

[32] M. Megharaj, I. Singleton, R. Kookana, and R. Naidu, "Persistence and effects of fenamiphos on native algal populations and enzymatic activities in soil," Soil Biology and Biochemistry, vol. 31, no. 11, pp. 1549-1553, 1999. 
[33] C. M. Tu, "Influence of pesticides on activities of invertase, amylase and level of adenosine triphosphate in organic soil," Chemosphere, vol. 11, no. 9, pp. 909-914, 1982.

[34] C. M. Tu, "Effects of selected pesticides on activities of invertase, amylase and microbial respiration in sandy soil," Chemosphere, vol. 17, no. 1, pp. 159-163, 1988.

[35] R. Jayamadhuri, Interactions between fungicides and microorganisms in soils from groundnut fields, M.phil dissertation, Sri Krishnadevaraya University, Anantapur, India, 2002.

[36] R. Jayamadhuri and V. Rangaswamy, "Influence of orghorous and carbamate insecticides on enzymatic activities of amylase, cellulase and invertase in two groundnut soil," Nature, Environment and Pollution Technology, vol. 4, pp. 385-393, 2005.

[37] C. M. Tu, "Effect of fungicides, captafol and chlorothalonil, on microbial and enzymatic activities in mineral soil," Journal of Environmental Science and Health - Part B, vol. 28, no. 1, pp. 67-80, 1993.

[38] H. Yan, D. Wang, B. Dong et al., "Dissipation of carbendazim and chloramphenicol alone and in combination and their effects on soil fungal: bacterial ratios and soil enzyme activities," Chemosphere, vol. 84, no. 5, pp. 634-641, 2011.

[39] H. Guo, G. Chen, Z. Lv, H. Zhao, and H. Yang, "Alteration of microbial properties and community structure in soils exposed to napropamide," Journal of Environmental Sciences, vol. 21, no. 4, pp. 494-502, 2009.

[40] A. Katayama and S. Rosendahl, "Effects of pesticides on cellulose degradation in soil under upland and flooded conditions," Soil Science \& Plant Nutrition, vol. 37, pp. 1-6, 2000.

[41] S. A. Omar and M. H. Abd-Alla, "Physiological aspects of fungi isolated from root nodules of faba bean (Vicia faba L.)," Microbiological Research, vol. 154, no. 4, pp. 339-347, 2000.

[42] R. M. Atlas, D. Pramer, and R. Bartha, "Assessment of pesticide effects on non-target soil microorganisms," Soil Biology and Biochemistry, vol. 10, no. 3, pp. 231-239, 1978.

[43] P. G. Vincent and H. D. Sisler, "Mechanism of antifungal action of 2,4,5,6-tetrachloroisophthalonitrile," Physiologia Plantarum, vol. 21, no. 6, pp. 1249-1264, 1968.

[44] A. S. Petker and P. K. Rai, "Effect of fungicides on activity, secretion of some extra cellular enzymes and growth of Alternaria alternate," Indian Journal of Applied and Pure Biology, vol. 7, pp. 57-59, 1992.

[45] A. E. Arinze and A. G. Yubedee, "Effect of fungicides on Fusarium grain rot and enzyme production in maize (Zea mays L.)," Global Journal of Pure and Applied Sciences, vol. 6, pp. 629-634, 2000. 

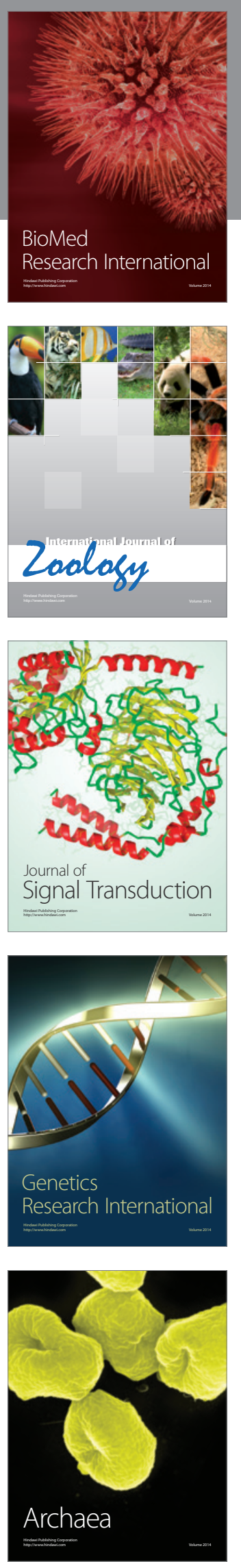
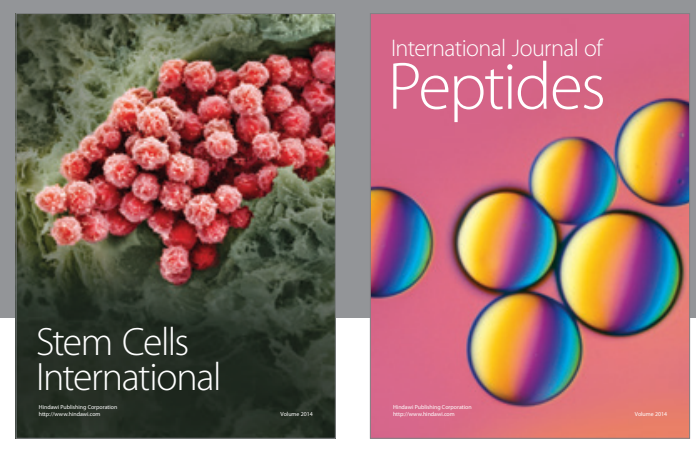

Submit your manuscripts at

http://www.hindawi.com
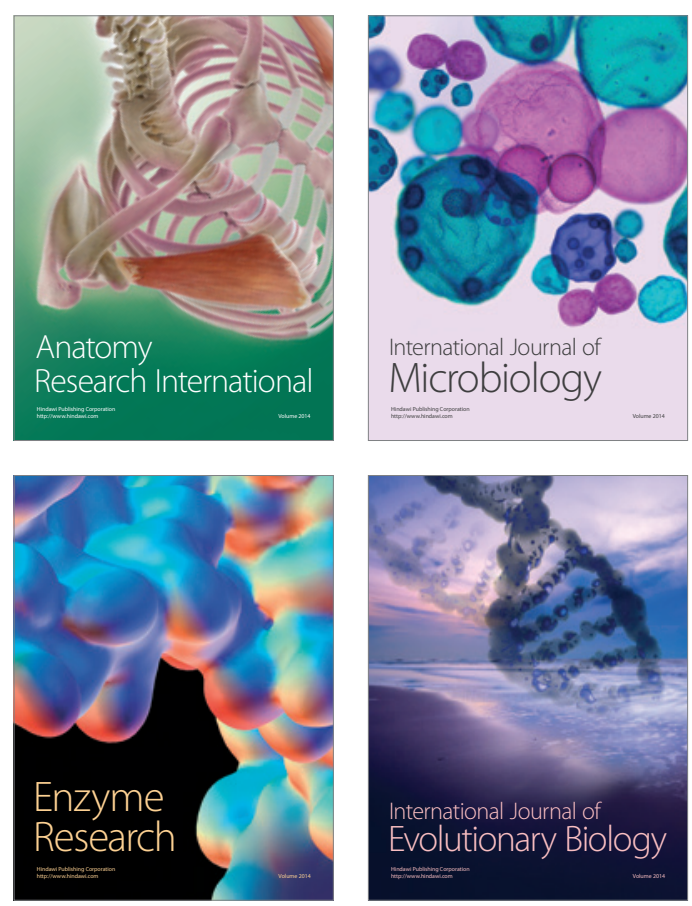
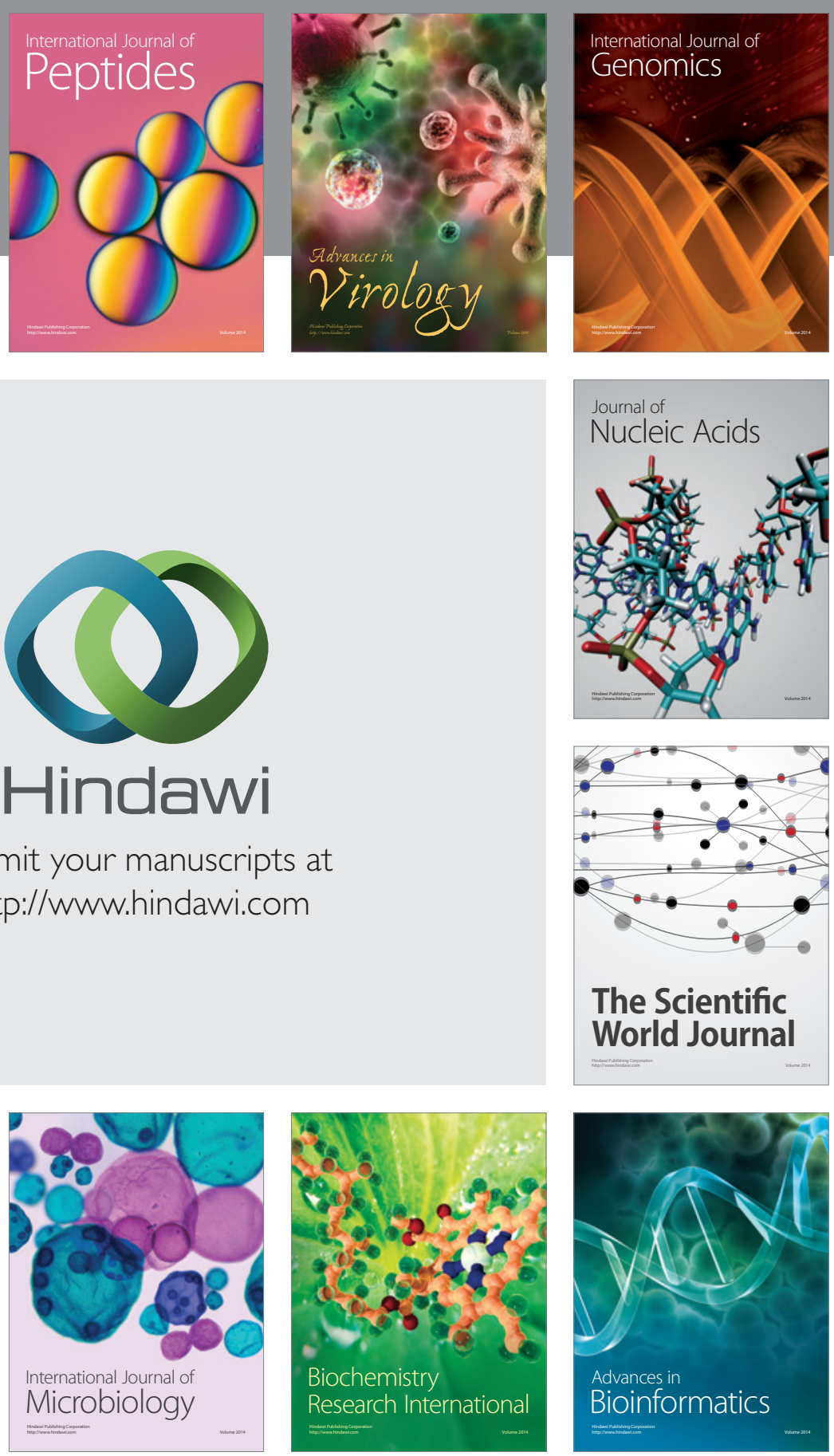

The Scientific World Journal
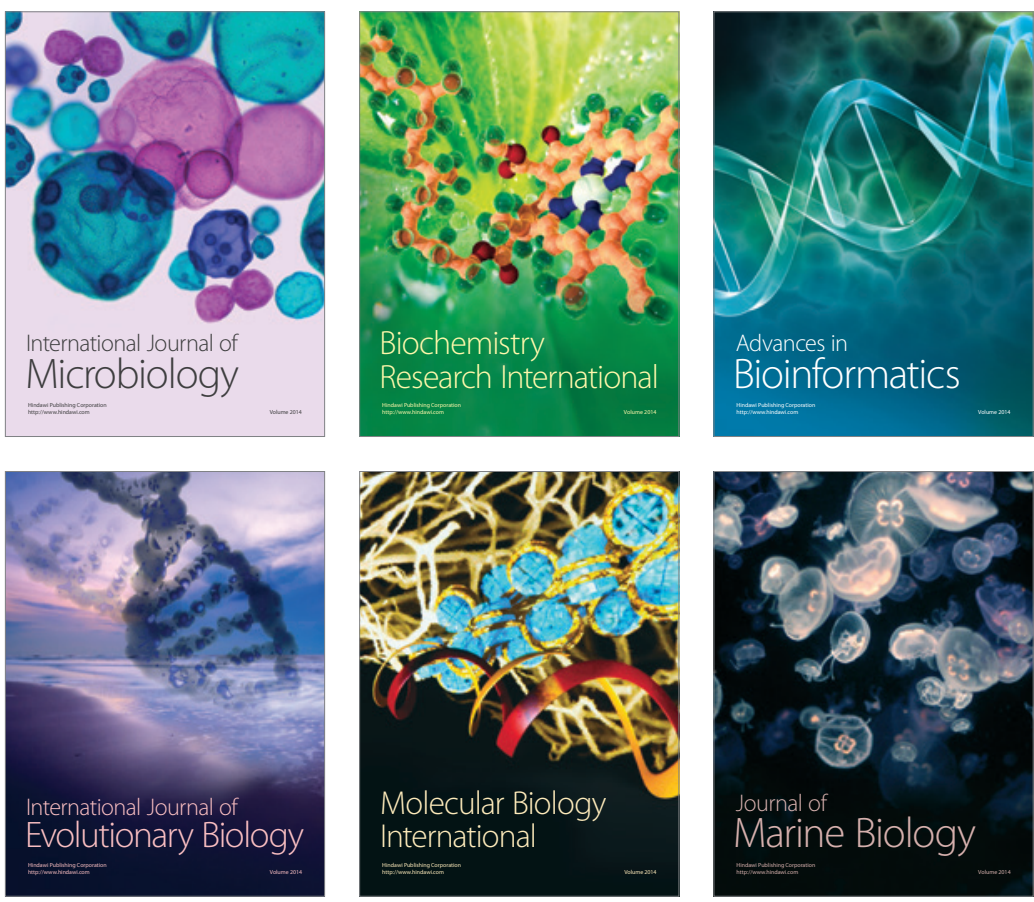